\title{
Technical deviations that generate medicines return: in the distributor in the southeast of Goiás
}

\section{Desvios técnicos que geram devolução de medicamentos: em distribuidora no sudeste goiano}

\author{
Larissa Juliana Patrocínio da Silva ${ }^{1}$ (D), Vagner Rosalem ${ }^{1}$ \\ 1Universidade Federal de Goiás - UFG, Departamento de Gestão de Negócios, Catalão, GO, Brasil. E-mail: \\ larissajps_@hotmail.com; vagner@hotmail.com
}

How to cite: Silva, L. J. P., \& Rosalem, V. (2020). Technical deviations that generate medicines return in the distributor in the southeast of Goiás. Gestão \& Produção, 27(1), e3564.

https://doi.org/10.1590/0104-530X3564-20

\begin{abstract}
Not all medicines received in the laboratory by distribution are in accordance. The purpose of the article was to identify concerning the technical and financial aspects that generate returns in a distributor of medicines through documentary analysis of company records for the period from 2014 to 2015 . Using this analysis, a spreadsheet was made with the types of technical deviations, such as breakdowns, lacks, short shelf life, divergence of lot, product exchange, packaging errors (lack of seal, lot printing error, shelf life printing error, faulty packing) and surplus product, product name, quantity, class, lot, laboratory, price and shelf life. A mapping of the processes was done, from the purchase of medicines to the receiving and storage of it by the company. Seven types of technical deviations were found, and its characteristics were presented. The total value of the loss to the distributor due to technical deviations was in total $\mathrm{R} \$ 914,864.57$ for the period between 2014 and 2015. It was also presented a proposal for a checklist to be used by distributors of medicines.
\end{abstract}

Keywords: Technical deviations; Distributor of medicines; Reverse logistics.

Resumo: Nem todos os medicamentos recebidos do laboratório pela distribuidora estão de acordo. O objetivo do artigo foi identificar em relação aos aspectos técnicos e financeiros os desvios que geram devoluções em uma distribuidora de medicamentos por meio de análise documental de registros da empresa no período de 2014 a 2015. Através desta análise foi feita uma planilha com os tipos de desvios técnicos, como avarias, faltas, validade curta, divergência de lote, troca de produto, erros de embalagem (falta de lacre, erro de impressão de lote, erro de impressão de validade, embalagem com defeito) e produto excedente, nome do produto, quantidade, classe, lote, laboratório, preço e data de validade. Foi feito um mapeamento dos processos desde a compra dos medicamentos até a etapa de recebimento e armazenamento dos mesmos pela empresa. Foram encontrados sete tipos de desvios técnicos e apresentado suas características. O valor total de prejuízo para a Distribuidora devido aos Desvios Técnicos foi no total de $\mathrm{R} \$ 914.864,57$ para período de 2014 e 2015 . Também foi apresentada uma proposta de um Check-list a ser usado por distribuidoras de medicamentos.

Palavras-chave: Desvios técnicos; Distribuidora de medicamentos; Logística reversa.

Received Nov. 3, 2016 - Accepted July 5, 2018

Financial support: None. 


\section{Introduction}

What makes medicine a differentiated product in its logistics are its peculiarities in the storage, distribution and transportation inside the distributors and it must strictly follow the legislation (Brasil, 2006). Medicine with the quality compromised offers a high degree of risk to the patient, and may not have the expected effect and making the treatment ineffective or even aggravating the clinical picture due to a degraded substance that can produce adverse effects to patients, who are already with the poor health (Marin et al., 2003).

A critical decision for the distributors is the laboratories qualification, seeking to obtain the best product to offer to their customers. The importance of laboratory selection raised the process requirements and had made it more complicated as a result of the quantity and nature of the criteria considered in the laboratories evaluation. The distributors are becoming more selective and require more of the laboratories. This requirement becomes evaluation criteria used to compare the laboratories. These may be quantitative, qualitative criteria (Lima et al., 2013a) and often conflicting as quality and price, because the higher the quality, the higher the price (Viana \& Alencar, 2012), using a relevance of methods to articulate different aspects in the evaluation of several alternatives.

To ensure the quality of the medicine that comes from the manufacturer and goes to the pharmacies and drug stores, the distributor needs to maintain the quality of all the medication while receiving. During the checking in receiving medications for distributors, it needs to check whether the physical products correspond to the purchase invoice, such as presentation, quantity, shelf life, lot and the carriage conditions for damaged drugs.

For this procedure be efficient, communication features are necessary, the equipment for the transportation of products, work instructions, and have an on-site flowchart. All these features contribute to the pattern of conduct among employees (Tuma et al., 2009).

Not all medicines received from the laboratory for distribution are in accordance. Technical deviations are conditions presented in the products during the manufacturing process, transportation or storage moved away from the quality parameters established (Rissi, 2011). These parameters according to the best practices established by the National Health Surveillance Agency (ANVISA), which cannot and must not be passed on to customers, such as pharmacies, drug stores and hospitals, and should be identified as soon as possible and try to return to the laboratory for a final destination.

However, distributors faced difficulties in performing reverse logistics, because some laboratories, as have large sales volume, use the power of the brand and create obstacles. Also, create the much red tape for this return, and sometimes do not want to increase the cost, locking processes and thus creating a loss to the distributor, since the distributor needs to manage this inventory, because it is unfit for marketing. The labs are examples of companies that could adopt the reverse logistics as strategy and competitiveness to the level of customer service (Leite, 2000).

Other companies when carrying out the reverse logistics can retrieve resell or give away products, concerning medicines the same does not occur due to the failure of manufacturers to ensure that medicines were manipulated, transported and stored correctly after its custody (Kabir, 2013).

Beyond Rissi's (2011) research while researching state of the art about the technical deviations, found only articles addressing technical deviations related to the quality of medicines that do not suit the parameters required for the manufacturer. These 
parameters caused, for example, allergic reactions in patients of hospitals and that are notified by hospitals included in the Sentinel Hospitals program, a program created by the Ministry of Health in 2001. Identifying these quality deviations is only possible after opening the medicine checking its status and after the patient reports the use, which the program registers as described in item 2.3 of this article. Technical deviations are not much cited as legal way addressed by the Health Surveillance as well as other studies, which motivates to perform researches like this.

Distributors must identify technical deviations on receipt since it has the central role of connection between the manufacturer and the final consumer and resolves to meet the Ordinance requirement no. 802/1998. The Ordinance that addresses that the distributors must maintain the quality of the products it distributes in all stages of distribution, responsible for any significant problems to the development of its activities (Brasil, 1998a).

An example of technical deviation is the divergence of the lot between the invoice generated by the manufacturer and lot delivered on the physical. It can be one of the most problematic technical deviations because it also directly affects the previously mentioned traceability and gathering orders from both the manufacturer and the ANVISA. Collection of medicines according to the RDC $n^{\circ} 55$ of 2005 (Brasil, 2005), aims to withdraw from the market determined(s) lot(s) with enough evidence or proof of quality deviation or cancellation of registration, to be implemented by the holder of the registration and its distributors.

These returns trigger a series of disorders and costs, for example, large volumes of return, taking up space, demanding time, costs and personnel to provide contact to carry out returns and if not successful, it will bring losses to the organization. There is a need for technical deviations management by distributors, where distributors and laboratories can avoid them and better manage their inventory.

When performing research for studies with this theme, there is a lack of publications about it, but Rissi (2011) presented important information and had guided this study for the definition of technical deviations. The author Rissi (2011) identified and assessed the technical deviations in receiving medications in a hospital as an instrument for the prevention of failures in the receipt and distribution of medicines, being an essential connection for the hospital to provide a quality service. The result was that the technical deviation of short shelf life represented almost half of all technical deviations found in the year.

The company studied is a branch of medicine distributor founded in 2009 with the beginning of its activities in 2010 in Goiás. This company receives medications from several laboratories and distributes to pharmacies, drugstores and hospitals in the Midwest, southeast and northeast of Brazil.

In this context, the question of which technical deviations generate returns of medications in a distributor why they happen and which are the linked values? In this way, the present article had the objective to identify, categorise and quantify about the technical and financial aspects the deviations that generate returns in a distributor of medications.

The article is presented in four sections; the first already presented is the introduction. The second section presents the theoretical reference; the third section presents the methodology, results and discussions. Finally, the fourth section presents the conclusions and concludes with the references used in this study. 


\section{Theoretical reference}

\subsection{Pharmaceutical supply chain}

The pharmaceutical supply chain is made up of the chemical and pharmaceutical stage. On the chemistry stage, the drugs are synthesised and they become the raw material of pharmaceutical products. In 2010, the pharmaceutical industry was composed of 44 companies responsible for this stage, acting as producers or distributors of pharmaceutical supplies. The pharmaceutical stage is where the production of the final product happens. This stage consists of several interconnected actors responsible for the supply of medications to the final consumer. The pharmaceutical stage occurs in pharmaceutical laboratories, and some cases subcontract a third party for the production of all or part of some products (Hiratuka et al., 2013). After the creation of the RDC $n^{\circ}$ 25/2007, the ANVISA (Brasil, 2007 ) regulated that laboratories could outsource the production stages, quality control analysis and medications storage.

To elucidate better which actors belong to the distribution it is presented the links in the supply chain. According to Reis \& Perini (2008), the first link in the pharmaceutical supply chain is the suppliers and service providers that attend pharmaceutical manufacturers. In this link, Brazil is dependent on many imports. Public and private manufacturers compose the second link, and it is where the pharmaceutical stage happens. According to the Federal Council of Pharmacy (CFF, 2016), in the 2016 Brazil had 456 manufacturers and 60 importers of medications.

The third link is the distribution, and the focus of this study, which is responsible for the medication that comes from the pharmaceutical manufacturers reach the retailers, hospitals and clinics for the final consumers' access. This third link is composed of Government supply centres, distributors, logistics operator, importers and distribution centres to private companies. According to the Federal Council of Pharmacy (CFF, 2016), in 2016 were registered 4147 medication distributors. Health service providers and retail compose the fourth and last link. At the end of all the links is located the final consumer or patient as noted in Figure 1. 


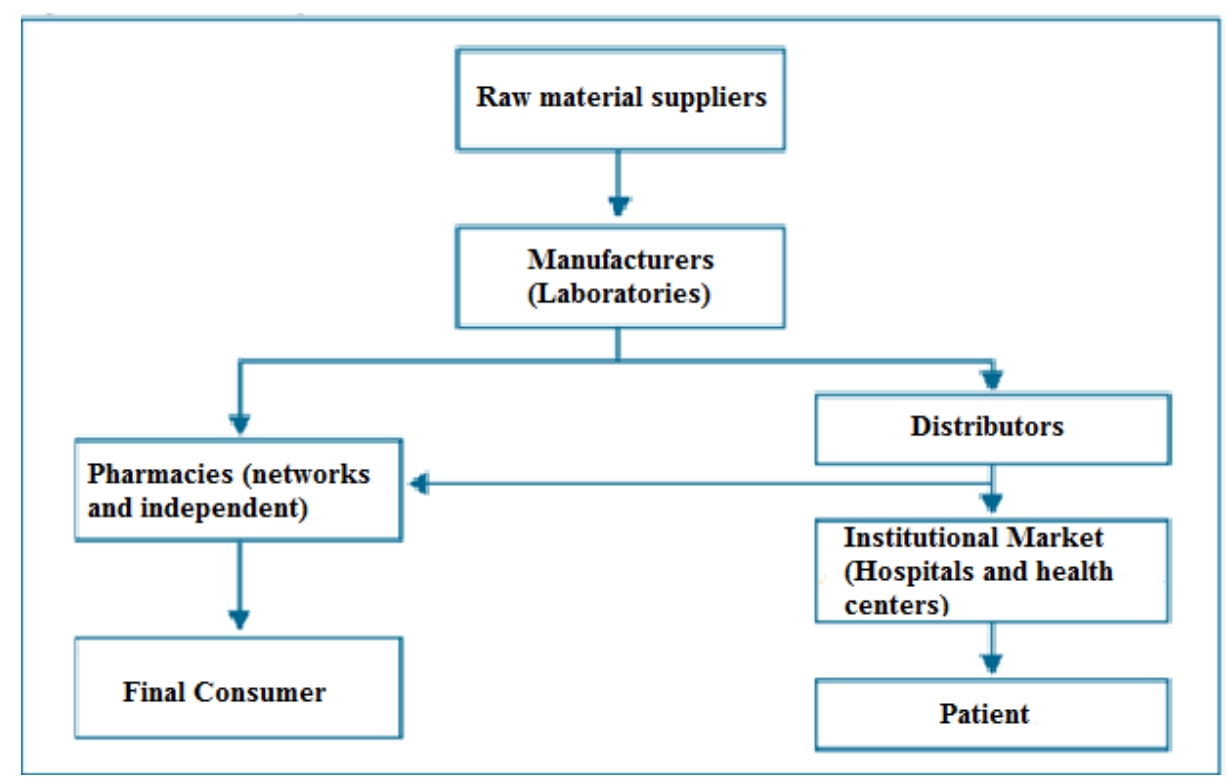

Figure 1. Pharmaceutical supply chain. Source: Machline \& Amaral (1998).

On the third link which is the object of study. The National Health Surveillance Agency (ANVISA) defines that the distributor is the one that exerts "directly or indirectly the wholesale trade" of products subject to health surveillance, according to the law $\mathrm{n}^{\circ}$ 5.991, of 17 December 1973 (Brasil, 1973). The production of the medicine has a long trajectory to go until it reaches the population.

In 2016, according to the Regional Council of Pharmacy of Goiás (CRF-GO, 2016), the State of Goiás has 220 effective medicines distributors. The pharmaceutical hub of Goiás occupies the third position in the national ranking, staying behind the states of Sao Paulo and Rio de Janeiro and predominantly positive results highlights the State of Goiás in the national scenario (Castro, 2004).

From the 90's, the pharmaceutical laboratories stopped act directly with the retail and began working directly with distributors, to achieve retail. Distributors in Brazil are among the wholesalers that have technology that is more modern, impeccable logistics structure and modern fleet and protected against theft (Sampaio \& Csillag, 2010).

In the third link, there is a logistics operator; this concept arose in the years 2000. This concept assumes the storage of medicinal products activities of different laboratories and directs them to distributors or wholesalers (Sampaio \& Csillag, 2010).

In addition to the physical retail trades that exceed 70 thousand pharmacies and drugstores in Brazil (Hiratuka et al., 2013), there is the possibility of the consumer purchase medicines through internet regulated by RDC $n^{\circ}$ 44/2009 (Brasil, 2009). The establishment that sells online should exist physically and provide the physical address, the name of the responsible pharmacist and contact for the consumer in the electronic address. In addition to being able to import medicines regulated by RDC $n^{\circ} 81 / 2008$ of ANVISA (Brasil, 2008), what does not prevent from happening by illegal means as well (Hiratuka et al., 2013).

With the entry into force of the resolution RDC $n^{\circ} 17 / 2012$ (Brasil, 2012), the ANVISA formalised that pharmacies had to perform distribution activity, since in different commercial places. So appears the new Distribution Centre actor of large pharmacies networks in Brazil. The distribution centre is a warehouse with the regional setting 
where products are received from several laboratories, which are fractionated to group the products in quantities that are sent to the nearest sale points (Bowersox \& Closs, 2001).

\subsection{Reverse logistics}

According to Leite (2009), it is possible to distinguish four operational areas of current corporate logistics: the logistics of supplies, manufacturing support, distribution and the reverse. The logistics of supplies, which corresponds to the actions necessary to meet the needs of material inputs; manufacturing support logistics, responsible for planning, storage and control of internal flows of the company; a distribution logistics, which is responsible for the delivery of requests received (Leite, 2009).

Finally, the reverse logistics, which is the newest area of logistics and is responsible for the return of the after-sales and post-consumer products and address its various destinations (Leite, 2009), that is, the handling of products back to the manufacturer or producer (Kabir, 2013). In this study, the focus is the field of reverse logistics after-sales products.

The reverse logistics is known as the material flow in the opposite direction to the one that goes from raw materials suppliers or supplies to the user (Corrêa, 2010). Figure 2 shows this flow.

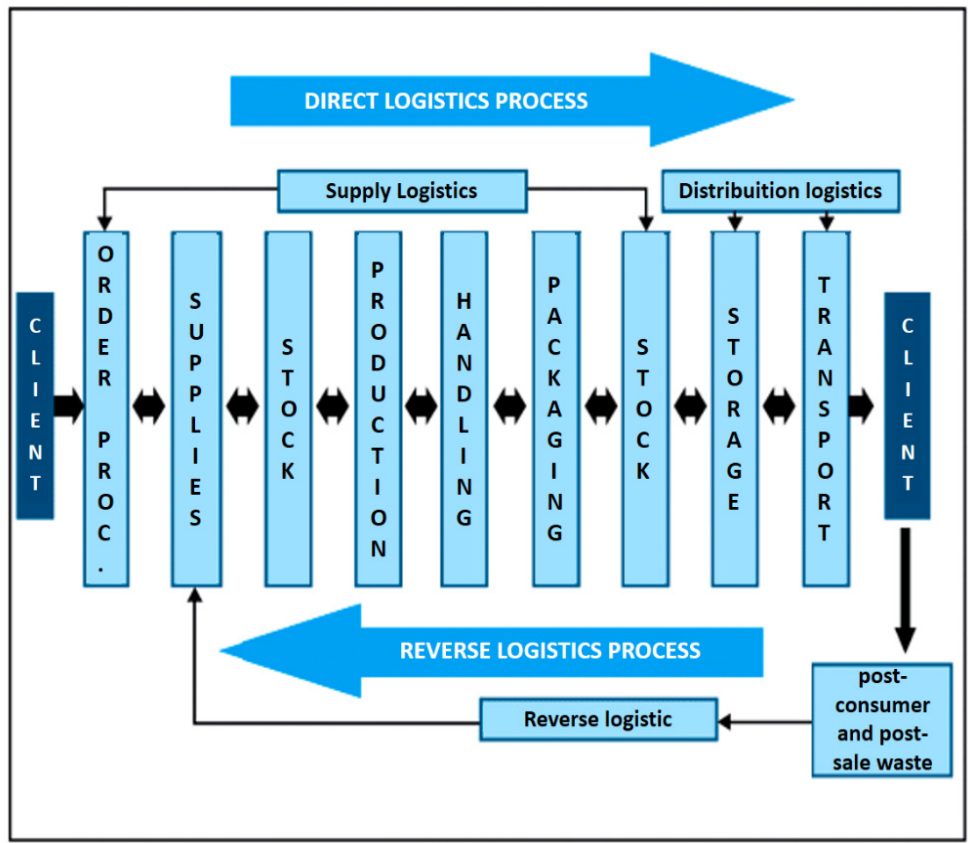

Figure 2. Direct supply chain management $x$ reverse supply chain management. Source: Rogers \& Tibben-Lembke (1999).

In Figure 2 there are post-consumer waste and after-sales that direct the path of reverse logistics. Post-consumer channels are constituted by the reverse flow of products that had original utility usefulness and that return to the productive cycle in some way for reuse, remanufacturing or recycling. Reverse channels after-sales are constituted for the return of a portion of products with little or no use, which flow in 
reverse direction, from final consumer to the retailer or manufacturer, from retailer to the manufacturer or between companies, motivated by problems related to the quality, shelf life, excessive inventory, consignment, etc. (Leite, 2009). This study highlights the reverse logistics from the distributor to the laboratory, reasons to be investigated and characterised.

Products that become obsolete, damaged or do not work must return to the point of origin to be adequately disposed of, repaired or reused (Gonçalves \& Marins, 2006). According to De Brito $(2004$, p. 21), reverse logistics is different from waste management, which deals with the collection and treatment of products to be disposed of and their legal implications.

Reverse logistics after-sales is the planning area, operation and control of the physical flow and after-sales products information with no or little use (Leite, 2002). This category includes after-sales errors in the processing of requests, guarantee given by the manufacturer, defects or malfunction of the product, transport damage, goods on consignment, season liquidation, closeouts (Leite, 2009).

In the after-sales reverse chain of a wholesaler, generally, the return of the products happens by the same way of direct distribution, that is, among the several members of the chain and between the consumer and distributor. So the more links, the more complex will be the reverse activities. Due to this, in recent years the managers have been questioning about the issues related to products return by retailers, wholesalers or virtual enterprises. Because it assimilates that diminishing returns generate a reduction of logistics costs for a company that looks forward to improving the level of service it offers to the market (Rocha et al., 2008).

The return of these products that had little or no use is due to problems, whose responsibility is the distributor or manufacturer or consumer dissatisfaction (Chaves et al., 2009). There is also a recall of products with problems on shelf life or problems noted after the sale, that are returned for legal reasons or customer service differentiation (Guarnieri et al., 2005).

\subsection{Technical complaints and quality deviations and medicines technicians}

The World Health Organization (WHO) defines pharmacovigilance as the set of activities related to the detection, assessment, understanding and prevention of adverse effects or any other problems related to medicines. The professionals, individually, must exercise pharmacovigilance reporting the suspected cases identified in their workplace, as hospitals and health posts related to the therapeutic failure, general physicochemical changes, or organoleptic characteristics; they may be related to fraud. The professionals should also encourage the use of only authorised manufacturers and registered medicines (OMS, 2005).

The technical complaint or quality deviation is any change or irregularity of a product, related to technical or legal aspects and may or may not cause damage to the health of the individual (OMS, 2005). Regarding the legal aspects, the counterfeiting cases related to medicines might be followed with more commitment by responsible authorities, being used to identify and combat the trade in illegal medicines, focusing more on safety and effectiveness of the product (Carvalho, 2005).

According to the OMS (2005), the responsibility in combating this type of infraction is a joint action of the pharmaceutical industry, the distributors, drug stores and 
pharmacies. The population and users, and health professionals leading each one to exercise the appropriated role of oneself within the system.

In Brazil, the post-marketing surveillance of health products is an area that requires further research (Rabelo, 2007). Many authors have written works related to Pharmacovigilance with emphasis on the description of adverse effects related to medicines (Coêlho, 1998), but little is known about the quality deviation of finished products, whose study also deserves special attention.

A medicine that has a suspicion of quality deviation, for example, change in colour, that has not been detected before use on the patient can be the cause of an adverse reaction. The quality deviation for medicines is the removal of the quality parameters established for a product or process, regulated by Resolution RDC $n^{\circ} 17$ of 2010 (Brasil, 2010). These can be related to organoleptic changes (change in colour, odour, taste, turbidity), physicochemical (precipitation, difficulty of dissolution, homogenization photosensitivity, thermosensitivity) or general changes (strange particles, lack of information on the label, registry problems, label or content switching, cracks and bubbles in the packing material).

However, the resolution does not make any recommendation on how a manufacturer should do the replacement of products with quality deviation. In this way, the industry solves the problem by the norms established by itself (Caon et al., 2012). It also does not report the process if the distributors identify these types of deviations in medicines.

It was only found studies addressing technical complaints of medicines in hospitals sentinels, hospitals selected by the ANVISA, to notify cases of techniques complaints and RAM (Caon et al., 2012; Lima et al., 2013b) the tool used to register technical complaints is the Notification System for Health Surveillance (NOTIVISA). However, in the NOTIVISA electronic website (Brasil, 2016), there are notifications data of sentinel hospitals, public health laboratories, professionals, universities among others. As Graph 1 shows, there was an increase in notifications of Technical Complaints and Adverse Events of medications, being predominantly the first every year, and with 65,704 notifications.

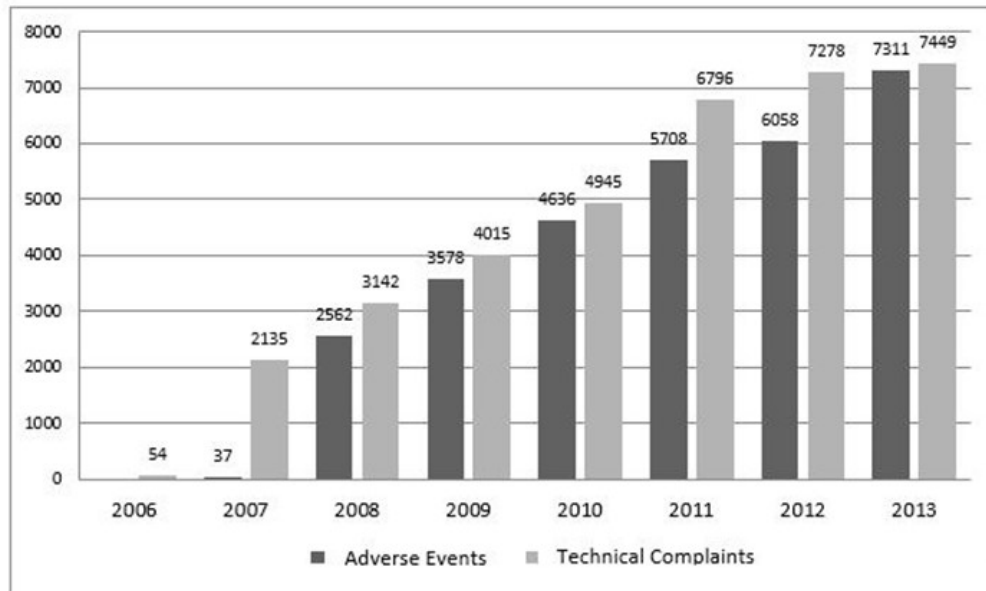

Graph 1. Total medicines notification by type of notification, since the NOTIVISA's implementation. Source: National Notifications System for Health Surveillance (NOTIVISA)

(Brasil, 2016). 
As the distributors are located in the centre of the chain, if they do not identify the technical deviations that come to them, they will pass along these products to hospitals, drugstores, clinics and up to the final consumer. This practice may bring inconvenience, losses with reverse logistics and may interfere with the company's reputation.

The literature does not make it clear how to identify these medicines with technical deviations. The closest is the RDC n $44 / 2009$ (Brasil, 2009), which reports that pharmacies and drugstores should establish the criteria to guarantee the origin and quality of products purchased. This RDC approaches that these products must be purchased legally from authorised and licensed distributors. These procedures may also be adopted in the distributors of all products received by the laboratories since there is no legislation for it.

\section{Methodology}

As proposed by Mattar (1996), data collection came from primary and secondary sources. A general reference about the study is a secondary source related to it and some data from the Federal and Regional Councils of Pharmacy, which provides numbers of pharmaceutical supply chain companies registered in 2015 and 2016. Besides, as a primary source, it was performed a case study with a survey and analysis of documents provided by the company studied.

According to Gil (1994), a case study is an empirical research that analyses a phenomenon in a real situation. It is also about detailed research, which explains the exact characteristics of a particular phenomenon or population, describing the real facts and events.

At the stage of data collection, it was done a documentary analysis of the records looking for technical deviations about a medicine distributor located in Catalão - GO, which had 18 active distributors in 2016, according to CRF of Goiás. While the general reference uses the contributions of various authors about a given subject, the documentary research is one that takes place based on the documents of public and private institutions (Tobar \& Yalour, 2001). It also uses material that has not received analytical treatment yet, or that can still be reformulated according to the purpose of the work (Diehl \& Tatim, 2004).

This distributor receives medicines from laboratories, identifies and separates those that generate returns, sorts them and makes records. This distributor has stock of medicines that are waiting for the return and a stock that they cannot return to laboratories.

The company selected for convenience is one of the three subsidiaries located in Catalão - GO, and works since 2010, in 2014 and 2015 are the busiest years of its medicines movement. Its headquarters is located in Hortolândia - SP, and together, they serve the region of Goiás, São Paulo, Espírito Santo and Fortaleza.

The analysis of the documents was from 2014 and 2015, containing the records of returned medicines and the reason. This period was determined due to the beginning of the company in 2010. It is the period that the records were standardised and before the company did not make these records and had losses until installing this standard.

A mapping of the processes was done, from the purchase of medicines to the receiving and storage of them by the company. On the receiving stage is where are the pictures and reports generated by the company including technical deviations. These documents are generated to report deviations and as proof to ask for refund and compensation for part of the laboratories. 
A worksheet was made using the analysis of documents for each of the types of technical deviations, such as malfunctioning, lacks, short shelf life, divergence of lot, product exchange, packing errors (lack of seal, lot printing error, shelf life printing error, faulty packing) and surplus product, product name, quantity, class, lot, price and expiration date. After the completion of the worksheet the treatment of the data was done and univariate quantitative analysis of them where was analysed variable by variable according to Freitas and Moscarola (2002, p. 14).

In other stages, additional information was obtained through personal non-participatory, and indirect observation by unique visits to the company studied. This observation is essential to understand the procedures and the description of them in text form and information as well as the photos used in the results.

The company selected for the study agreed to make available all documents, records and photos of medicines returns and the documents used during the procedures. For being a documental analysis, there was no need to submit this study to a Research Ethics Committee analysis, the ethics were respected, and the request for confidentiality of the company's name is respected, so the company will be called Distributor.

The Distributor has provided all records of technical deviations made in the period from 2014 and 2015, 315 records. These records contain the type and registration number, date, supplier, shipping company, product, quantity, lot, shelf life, price, photo and description of the occurrence. All this information was tabulated in Microsoft Exce ${ }^{\circledR}$ creating a folder for all the photos and selecting the ones that would represent each type of technical deviation. All the information on the worksheet have been rechecked and the products information added to the worksheet according to its registration at ANVISA (Brasil, 2015).

\section{Results and discussions}

According to the documents of Standard Operating Procedures (SOPs) from the Distributor, receiving medicine involves various sectors of the company, customers and suppliers and shipping companies. Firstly, the request by the client happens or by the Distributor stock sector. The purchase sector of the Distributor passes on the request to suppliers that separate and the shipping company delivers on the medicine distributor. As soon as they are unloaded from the vehicle, the Distributor Checking sector checks the medicines according to the request, invoice, and checks the packaging conditions, boxes that are damaged, checks products, lot, quantity e shelf life.

After the checking, it is carried out verification of products with the pharmacist in charge performs possible technical deviations and pictures and records. After registration, the pharmacist needs to make notes in the invoice stub and the company's documents, because they only carry out reimbursements if they make these safe conducts on the receiving of products. After this procedure, the products are transported to the distributor's return area to be stored, and the products stay there until the distributor makes contact with the supplier for the reverse logistics and financial reimbursement of the same.

The products that do not find possible returns go straight to the stock and storage until they customers can receive them. If the suppliers recall a product, the distributor performs the reverse logistics of its customers until its warehouse to await collection by the suppliers and make records of them. From these procedures analysed was created a flowchart with the sequence adopted by the distributor to receive medicines (Figure 3): 


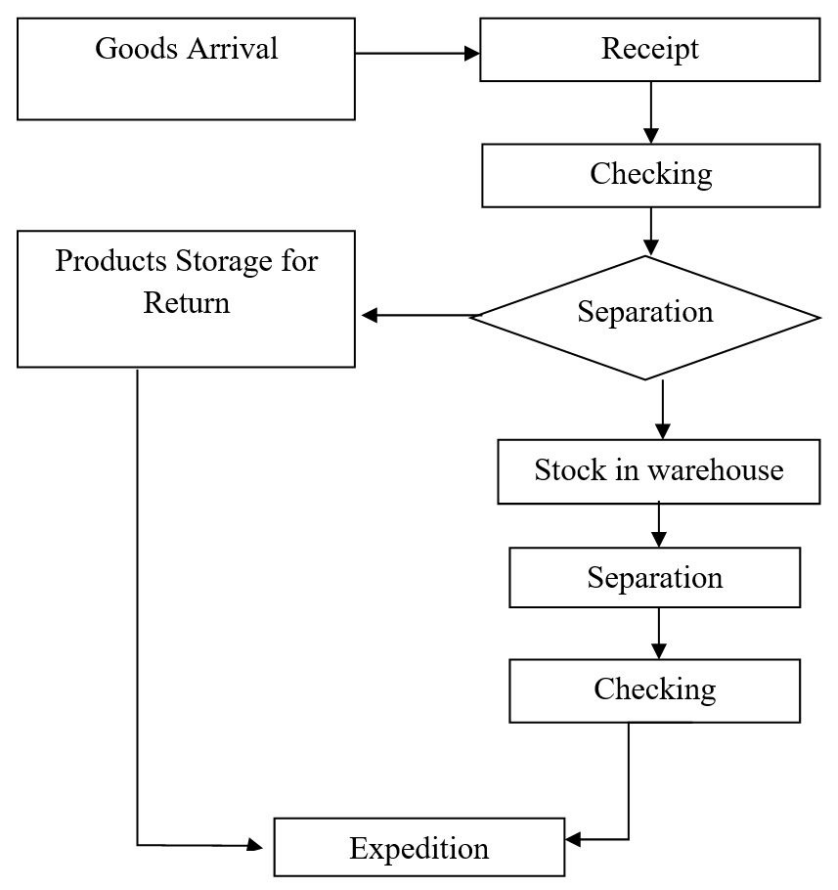

Figure 3. Flowchart of the process for receiving medicines. Source: Prepared by the authors.

The study could identify seven types of technical deviations, which are a malfunction, lack, lot exchange, product exchange, packaging, error and shelf life and surplus short. The following will present each technical deviation with their characteristics so that any medicines distributor and even other actors of the pharmaceutical supply chain can identify them.

Some terms that we will use will be primary packaging, secondary packaging and shipping box. Primary packaging according to the RDC $n^{\circ} 35$ from 25th of February 2003 (Brasil, 2003) is where the medicine is directly stored, as the blister pack, glass or ampoule and secondary where the primary is stored, in other words, the box containing the name and information about the medicine. The shipping box is the one that the laboratory standardises the cardboard, and certain amounts of medicines are put inside to be transported.

BREAKDOWN: Breakdown is a type of technical deviation where the medicine suffers impact either in the supplier, shipping, unloading or in storage. This deviation happens by mistake and lack of care when handling this type of product, which is fragile and prevents the same to go into the market because customers refuse to accept a product that is not in perfect condition. In many breakdowns observed in the pictures provided by the company, there were secondary packaging and defective shipping boxes.

The records were found breakdowns by impact, wet, torn, dirty, insects, broken glassware and that they suspect are problems mostly caused by transport companies. In one of the records reported that the shipping box was with a shoe mark on it, suggesting that someone stepped on a box ignoring the warning "Fragile".

LACK: Lack is a type of technical deviation when is missing the whole boarding box or the medication unit inside the boarding box or primary packaging inside the secondary packaging. According to records in the first case in which the boarding box is missing, it usually happens due to lost or an error of the supplier or the transport 
company and that are located and deliver to the Distributor, in case it is not established, it becomes the supplier responsibility.

In the second case, an error may occur by the laboratory or by people, who have had contact with the product, losing the medication. The third case suggests manufacturing error when the primary packaging was not inserted in the second packaging and the package was sealed. It is the only type of technical deviation that is not separated to return, and it is only waited for the reimbursement or credit according to the value of the product.

PRODUCT EXCHANGE: This third type of technical deviation refers to the exchange of the product or exchange of a product by another. This Exchange can be requested for invoice and invoice for the product itself. As an example in the records, the product was required, and in the invoice presented that the product was a lotion and was delivered the same product, but in the shampoo form. The recognition of this kind of technical deviation depends on the checking of the request with the invoice of the products delivered.

LOT EXCHANGE: Lot according to the concept presented by the ANVISA (Brasil, 2019 ) is the amount of medicine, produced in a manufacturing cycle, whose essential characteristic is the homogeneity. So the lot number is the printed designation on the product label covered by this regulation, which allows the identification of the lot or departure that it belongs, and, in case of need, find and review all manufacturing operations and conducted an inspection during production. In this technical deviation the received product is following the request and the invoice, however, the lot number of the medicine is divergent in the invoice issued by the supplier.

PACKAGING ERROR: According to the description presented by the ANVISA (Brasil, 2019), the packaging is wrapping, container or any form of removablepackaging, or not, intended to cover, package, to pack, protect or keep the medicines. In this package, there is the information with the name of the medicine, manufacturer, registry number, name of the responsible pharmacist, customer service phone, lot number, manufacturing date, shelf life, the seal of traceability or reactive ink and security seal.

The technical deviation for packing error is when some of these characteristics are wrong, defective or missing. One of the reports said that on a medicinal product where it is printed the lot did not have the fourth number; one of the numbers that compose and identifies the lot was not printed. However, in another report said that the paint of the lot and shelf life blurred and confused the identification of the shelf life.

SURPLUS: Surplus is the type of deviation in which the medicines are delivered in quantities higher than requested or higher than the invoice. The company cannot receive products without the record on the invoice. Either this kind of deviation may occur by the supplier that sent more medicines than necessary or by the shipping company, which mixes deliveries.

SHELF LIFE: According to the RDC n 35/2003 (Brasil, 2003), the expiry date is the end date for the use of the Pharmaceutical Product defined by the manufacturer, based on its respective stability tests, kept the storage conditions and transport, established by the manufacturer. The time for the medicine reaches the Distributor, be sold to retail and purchased by the consumer can be great and a short time for the consumption of this medicine. Then the Distributor provides a minimum time to accept the shelf life of the medicines delivered by the supplier.

In this case, the Distributor stipulated that only medicines with a year or more of shelf life could be received. Therefore, the technical deviation presented here are those medicines that the supplier delivers with a shelf life less than one year. 
In total were analysed 315 records, distributed by seven types of technical deviations. In some records, there was more than one type of technical deviation and several different products. The year 2014 obtained 67 records and 2015 obtained 248 records, an increase of $270 \%$ of these documents. The type of technical deviation that obtained the most amount was the breakdown and the surplus with the least amount of records, only one, as noted in Table 1. The month of 2015 with more records was December with 23 records and in 2015 was the month of March with 30 records. The last percentage column refers to the total amount of two years of records for each type of technical deviation found.

Table 1. Ranking of records by deviation.

\begin{tabular}{lcccc}
\hline \multicolumn{1}{c}{ Technical Deviation } & $\mathbf{2 0 1 4}$ & $\mathbf{2 0 1 5}$ & Records & Percentage \% \\
\hline Breakdown & 55 & 179 & 234 & 74 \\
\hline Short Shelf Life & 0 & 47 & 47 & 15 \\
\hline Lacks & 9 & 13 & 22 & 7 \\
\hline Lot Exchange & 1 & 5 & 6 & 2 \\
\hline Product Exchange & 1 & 2 & 3 & 1 \\
\hline Packaging error & 0 & 2 & 2 & 1 \\
\hline Surplus & 1 & 0 & 1 & 0 \\
\hline TOTAL & 67 & 248 & 315 & 100 \\
\hline
\end{tabular}

Source: Prepared by the authors.

The Distributor receives medicines of 23 different suppliers, of which only three have not obtained any technical deviations record. With this information, as noted in Table 2, was created a ranking of records per supplier.

The suppliers were organised in descending order in quantity of technical deviation records, and the name of each supplier has been preserved at the request of the Distributor, adopting a number to represent each one. The supplier 1 had some discrepant records among all other suppliers and being a supplier with high returns of medicines.

Table 2. Records per supplier.

\begin{tabular}{cccc}
\hline Supplier & Records & Supplier & Records \\
\hline Supplier 1 & 150 & Supplier 13 & 5 \\
\hline Supplier 2 & 28 & Supplier 14 & 4 \\
\hline Supplier 3 & 26 & Supplier 15 & 2 \\
\hline Supplier 4 & 12 & Supplier 16 & 2 \\
\hline Supplier 5 & 12 & Supplier 17 & 1 \\
\hline Supplier 6 & 12 & Supplier 18 & 1 \\
\hline Supplier 7 & 12 & Supplier 19 & 1 \\
\hline Supplier 8 & 11 & Supplier 20 & 0 \\
\hline Supplier 9 & 9 & Supplier 21 & 0 \\
\hline Supplier 10 & 9 & Supplier 22 & 0 \\
\hline Supplier 11 & 8 & Supplier 23 & \\
\hline Supplier 12 & 7 & & \\
\hline
\end{tabular}

Source: Prepared by the authors. 
In the analysis performed on 150 records of breakdown technical deviations were found 18 different suppliers, 14 different shipping companies, 232 invoices distributed in the records, that is, there was more than one invoice in many records, they were grouped on the day of the receiving in a single record. It was found 349 product presentations in the records and a total of 2819 units of these products. The one with the smallest amount was the one with 1 unit, and the most significant amount found was 115 units of the same product. The cheapest found was $R \$ 0.60$ and the most expensive was $\mathrm{R} \$ 92.37$.

In the total amount of units of each product, the cheapest found was $R \$ 0.99$, and the most expensive was $\mathrm{R} \$ 1825.80$. The total value of all products in all records $\mathrm{R} \$ 23,874.99$ was obtained. Taking into consideration the type of medicines, reference medicinal products have been found, generic, similar and phytotherapic. It was the only type of technical deviation that presented a controlled product following the ordinance $n^{\circ} 344 / 1998$ (Brasil, 1998b) where approves the technical regulation on substances and medicines which are subject to exclusive control.

Consulting ANVISA's website (Brasil, 2015) in "Product inquiry", it was verified the therapeutic class of every medicine found in records and were found in a total of 58 therapeutic classes' e five products which were phytotherapic and did not have a class defined in the ANVISA's website. Of these 58 classes, the class which obtained a greater quantity of products and units was "Scabicides and other Ectoparasiticides".

In the analysis performed in 22 records about technical deviations of lack, were found eight different suppliers, six different shipping companies, 22 invoices, 36 product presentations and 6738 units. The lower unit value was $R \$ 0.58$, and the higher unit value was $R \$ 61.51$, and the total value of lacked products was $R \$ 91,516.06$.

The one with the smallest amount was the one with 1 unit, and the most significant amount found was 1848 units of the same product. Reference medicinal products have been found, generic and similar, no phytotherapic. 21 therapeutic classes were found while consulting the ANVISA's website (Brasil, 2015) and two products did not present the class on the website. The class "anti-hypertensive" is the most frequent considering the lacks.

In the technical deviation of lot exchange, it was observed that they were originated from four different suppliers, $50 \%$ the records were from similar medications, the therapeutic class with the highest incidence was "Non-narcotics Painkillers". 272 units were with the lot swapped and the unit with the higher value was $R \$ 44.64$. The total value of lot exchange was $R \$ 2,595.14$.

In the technical deviation of products exchange, there was a total of 3 records presenting three suppliers, there was a record with the product presentation different, one with a different pharmaceutical form and the other with the difference in the milligram of the requested and the one delivered. In the first record, the value of the products requested was $R \$ 231.00$, and the value of the products delivered was $\mathrm{R} \$ 4,636.80$, which means $2007 \%$ increase in value. On the third record, were delivered 6000 product units swapped. The total loss of the products that were requested by the Distributor was $R \$ 41,887.68$.

The two records of deviation for packaging error were from two different suppliers, in one of them, the shelf life and the medicine lot were not printed on the package. In the second record, the medicines did not have the security seals, or it was unsealed. The total value of the products is $\mathrm{R} \$ 1,356.60$.

In surpluses cannot adopt the values as losses to the Distributor, because it is only loss to the supplier or shipping company that sent the more products. The number of 
units of medicines in the single record was 220 units, and the value is unknown for not appearing in the invoice.

In Technical Deviation by Short Shelf Life, the Distributor adopts one year for the maximum period to receive the medicines, where all the suppliers are advised at the time of registration and application. All medicines sent by the supplier and on the day of the receipt present shelf life less than a year is considered Technical Deviation by Short Shelf Life. This practice is adopted, because the time for the medicine to be received, be in stock, be sold, delivered to the client and reaches the final consumer is too long and if it is accepted less than a year, may result in a loss to the Distributor due to the shelf life.

In all 47 records, there were 11 suppliers. The records showed 58 product presentations, and in its majority, they are medicines reference. They also showed 35442 product units, the unit of the highest value is $R \$ 143.04$, and the total value of the products is $R \$ 753,634.10$.

When reviewing the values found, presented in Graph 2, the loss to the Distributor due to Technical Deviations was R $\$ 914,864.57$ from 2014 to 2015 . In other words, an average of $R \$ 457,000.00$ of loss per year for this company studied.

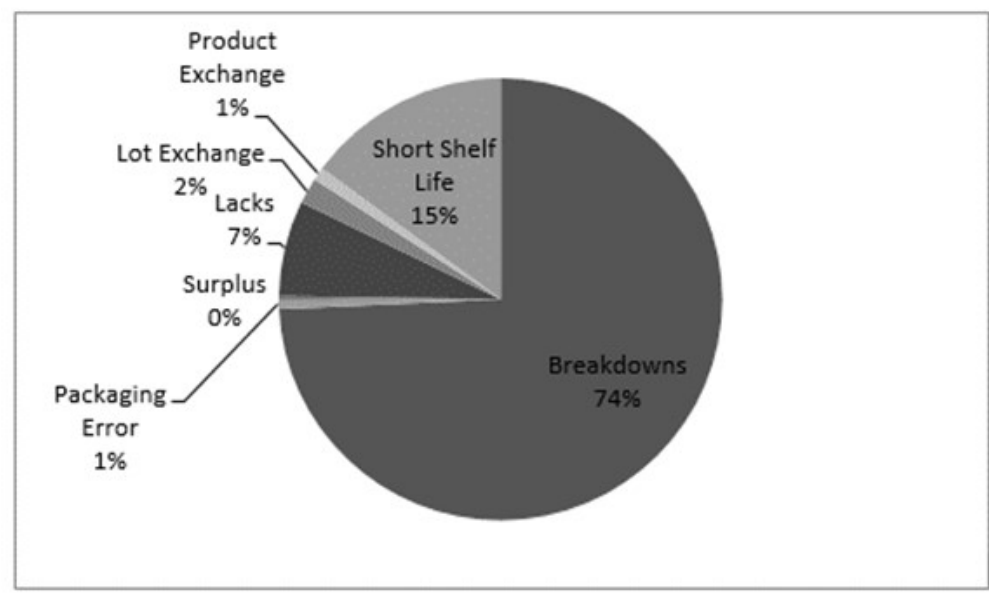

Graph 2. Percentage of technical deviations observed in receiving medicines during the period from 2014 to 2015. Source: Prepared by the authors.

By Graph 2, it is possible to see how the technical deviation of breakdowns represents $3 / 4$ of the deviations found and it is also possible to see the deviations of Product Exchange, Lot Exchange, Surplus and Packaging Error. Also, still have a single percentage unimpressive if compared to Lacks deviation, Short Shelf Life and Breakdowns.

It is proposed a Checklist for distributors of medicines identify Technical Deviations on receiving medicines. All the requirements are presented in the Annex A.

The checklist requires information about the supplier, the shipping company, the receiving medicines and an after-sales assessment. This information allows the Distributor to have in only one document information that may assist them to qualify the best suppliers, identify shipping companies that present many problems in deliveries, it also provides detailed information about the medicines checking, which avoids losing details that can bring future losses to the company. 
It allows the client to evaluate the post-sales provided by the supplier, in which can be registered the entire communication between them, how were the medicines return with technical deviations, how much time was spent to be resolved and comments. Comments, for example, any difficulties or employees of the suppliers that can help to speed up the return process and that could help in future records of the same supplier, because the sooner solved, less loss will bring to the Distributor.

\section{Conclusions}

The correct implementation of the reverse logistics process allows managing, not just to manage the reverse product flow efficiently, but also to identify the opportunities to reduce unwanted returns and manage reusable assets (Rogers et al., 2002). The search for avoiding losses is a reality for the companies and also for medicines distributors. The case study gave relevant information on the quantity and values of losses caused by Technical Deviations in medicines.

The study presented much information from the records held by the company studied, but they were only possible through the pharmacist perception to observe and draw up these records with the information necessary for the use of the company to make the returns and reimbursements. The study brought information capable of being used by distributors to perform a selection and qualify the suppliers to reduce the occurrence and frequency of the deviations observed.

Distributors may also use this information to manage their stock of medicine returns. So the suppliers can use this information to select the best shipping companies to take their products to the medicines distributors and generate some of these Technical Deviations.

This study also brought as the perception that the medicines distributors the need to provide training for its employees with the features presented for each Technical Deviation, providing the information so it can be identified as soon as possible since the laboratories create obstacles to the medicines returns. This procedure also helps prevent further loss and a negative image in front of customers.

The Checklist presented is a tool that does not depends on high investment for the distributors and also for the employees to have on their hand a tool to record all the Technical Deviations observed. It can also be used the feedback at the end of the register so that the distributors can evaluate the performance of suppliers concerning the return on the same document.

This article was necessary to evaluate the small number of studies in the field and confirms the State of the art of this theme, and that presents the importance and need to find more on the subject. Defined each deviation found with description and pictures, expect a greater clarity for those involved in the production chain since the resolutions created by the regulatory agency do not make it clear which deviations would be found.

The control by Check-list gives a higher quality and also security of medicines to the final consumer. Controlling this technical deviation in the middle of the pharmaceutical chain prevents many errors that could reach the end of the chain and also diminishes the path taken in reverse logistics, giving less loss and less risk to the health of users.

This study may also contribute to the construction of models adapted to reality and Brazilian law as studied by Narayana et al. (2014) where they discussed the connection between the network design of reverse logistics and the main activities in the returns management and created a platform for the development of a simulation model. 


\section{References}

Bowersox, D. J., \& Closs, D. J. (2001). Logística empresarial: o processo de integração da cadeia de suprimento. São Paulo: Atlas.

Brasil. Agência Nacional de Vigilância Sanitária - ANVISA. (1973, 19 de dezembro). Lei $n^{\circ}$ 5.991, de 17 de dezembro de 1973. Dispõe sobre o controle sanitário do comércio de drogas, medicamentos, insumos farmacêuticos e correlatos, e dá outras providências. Brasília, DF: Diário Oficial da República Federativa do Brasil. Retrieved in 2015, October 12, from https://www.planalto.gov.br/ccivil_03/leis//5991.htm

Brasil. Agência Nacional de Vigilância Sanitária - ANVISA. (1998a, 9 de outubro). Portaria $n^{\circ}$ 802, de 8 de outubro de 1998. Brasília, DF: Diário Oficial da República Federativa do Brasil. Retrieved in 2015, October 12, from http://bvsms.saude.gov.br/bvs/saudelegis/anvisa/1998/prt0802_08_10_1998_rep.html

Brasil. Agência Nacional de Vigilância Sanitária - ANVISA. (1998b). Portaria $n^{\circ} 344$ de 12 de Maio de 1998. Aprova o Regulamento Técnico sobre substâncias e medicamentos sujeitos a controle especial. Brasília, DF: Diário Oficial da República Federativa do Brasil. Retrieved in 2016, May 4, from http://bvsms.saude.gov.br/bvs/saudelegis/svs/1998/prt0344_12_05_1998_rep.html

Brasil. Agência Nacional de Vigilância Sanitária - ANVISA. (2003, 7 de março). Resolução $R D C n^{\circ} 35$, de 25 de fevereiro de 2003. Determina todos os estabelecimentos Distribuidores e Fracionadores de Insumos Farmacêuticos o cumprimento das diretrizes estabelecidas no Regulamento Técnico de Boas Práticas de Distribuição e Fracionamento de Insumos Farmacêuticos. Brasília, DF: Diário Oficial da República Federativa do Brasil. Retrieved in 2016, September 20, from https://www.diariodasleis.com.br/busca/exibelink.php?numlink=1-9-34-2003-02-25-35

Brasil. Agência Nacional de Vigilância Sanitária - ANVISA. (2005, 21 de março). Resolução $R D C n^{\circ} 55$, de 17 de março de 2005. Brasília, DF: Diário Oficial da República Federativa do Brasil. Retrieved in 2015, October 12, from http://www.vigilanciasanitaria.sc.gov.br/index.php/download/category/137farmacovigilancia?download=806:resolucao-rdc-n-55-2005

Brasil. Ministério da Saúde. (2006). Assistência farmacêutica na atenção básica: instruções técnicas para sua organização. Brasília: Ministério da Saúde.

Brasil. Agência Nacional de Vigilância Sanitária - ANVISA. (2007). RDC nº 25 de 29 de Março de 2007. Dispõe sobre a terceirização de etapas de produção, de análises de controle de qualidade e de armazenamento de medicamentos. Brasília, DF: Diário Oficial da República Federativa do Brasil. Retrieved in 2016, May 25, from http://bvsms.saude.gov.br/bvs/saudelegis/anvisa/2007/res0025_29_03_2007_rep.html

Brasil. Ministério da Saúde. (2008, 11 de novembro). Resolução RDC n 81, de 5 de novembro de 2008. Dispõe sobre o Regulamento Técnico de Bens e Produtos Importados para fins de Vigilância Sanitária. Brasília, DF: Diário Oficial da República Federativa do Brasil. Retrieved in 2016, April 8, from http://portal.anvisa.gov.br/wps/wcm/connect/02dd8800474597549fd3df3fbc4c6735/RDC+n o++81+2008.pdf?MOD=AJPERES

Brasil. Agência Nacional de Vigilância Sanitária - ANVISA. (2009, 18 de agosto). Resolução $R D C n^{\circ} 44$, de 17 de agosto de 2009. Dispõe sobre boas práticas farmacêuticas para o controle sanitário do funcionamento, da dispensação e da comercialização de produtos e da prestação de serviços farmacêuticos em farmácias e drogarias e dá outras providências. Brasília, DF: Diário Oficial da República Federativa do Brasil. Retrieved in 2016, April 27, from http://cfo.org.br/wp-content/uploads/2010/02/180809_rdc_44.pdf

Brasil. Agência Nacional de Vigilância Sanitária - ANVISA. (2010). Resolução RDC $n^{\circ} 17$, de 16 de abril de 2010. Dispõe sobre as Boas Práticas de Fabricação de Medicamentos. Brasília, DF: Diário Oficial da República Federativa do Brasil. Retrieved in 2015, October 12, from http://bvsms.saude.gov.br/bvs/saudelegis/anvisa/2010/res0017_16_04_2010.html 
Brasil. Agência Nacional de Vigilância Sanitária - ANVISA. (2012, 22 de março). Resolução $R D C n^{\circ} 17$, de 22 de março de 2012. Dispõe sobre a alteração da Resolução da Diretoria Colegiada - RDC n. ${ }^{\circ} 222$, de 28 de dezembro de 2006, que dispõe sobre os procedimentos de petição e arrecadação eletrônica no âmbito da Agência Nacional de Vigilância Sanitária - ANVISA e dá outras providências. Brasília, DF: Diário Oficial da República Federativa do Brasil. Retrieved in 2015, June 8, from http://bvsms.saude.gov.br/bvs/saudelegis/anvisa/2012/rdc0017_22_03_2012.html

Brasil. Agência Nacional de Vigilância Sanitária - ANVISA. (2015). Consulta a medicamentos. Retrieved in 2015, October 3, from https://consultas.anvisa.gov.br/\#/medicamentos/

Brasil. Agência Nacional de Vigilância Sanitária - ANVISA. (2016). Sistema de notificações para a vigilância sanitária. Brasília: ANVISA. Retrieved in 2016, April 20, from https://www8.anvisa.gov.br/notivisa/ frmlogin.asp

Brasil. Agência Nacional de Vigilância Sanitária - ANVISA. (2019, 22 de agosto). RDC $n^{\circ} 301$ de 21 de Agosto de 2019. Dispõe sobre as Diretrizes Gerais de Boas Práticas de Fabricação de Medicamentos. Brasília, DF: Diário Oficial da República Federativa do Brasil. Retrieved in 2019, December 6, from http://www.in.gov.br/web/dou/-/resolucao-rdcn-301-de-21-de-agosto-de-2019-211914064

Caon, S., Feiden, I. R., \& Santos, M. A. (2012). Desvios de qualidade de medicamentos em ambiente hospitalar: identificação e avaliação das ocorrências. Revista Brasileira de Farmácia Hospitalar e Serviços de Saúde, 3, 23-26.

Carvalho, A. C. (2005). O impacto negativo da pirataria no cenário mercadológico e as dificuldades no combate à falsificação. Revista do IBRAC, 12(3), 47-84.

Castro, S. D. (2004). Sistemas produtivos locais no Estado de Goiás: o caso da Indústria Farmacêutica do Eixo Goiânia - Anápolis (No 004/2000, Convênio IPEA/ANPEC). Goiânia: [s.n.]. Mimeografado. Relatório final.

Chaves, G. L. D., Alcântara, R. L. C., \& Assumpção, M. R. P. (2009). Medidas de desempenho na logística reversa: o caso de uma empresa do setor de bebidas. Relatórios de Pesquisa em Engenharia de Produção, 8, 2, 1-23.

Coêlho, H. L. (1998). Farmacovigilância: um instrumento necessário. Cadernos de Saúde Publica, 14(4), 871-875. http://dx.doi.org/10.1590/S0102-311X1998000400030. PMid:9878921.

Conselho Federal de Farmácia - CFF. (2016). Boletins com dados de 2016. Brasília. Retrieved in 2017, January 8, from http://www.cff.org.br/pagina.php?id=801\&titulo=Boletins

Conselho Regional de Farmácia de Goiás - CRF-GO. (2016). Dados (personal message). Message received by presidencia@crfgo.org.br, in 2016, April 25.

Corrêa, H. L. (2010). Gestão da rede de suprimentos: integrando cadeias de suprimento (3. ed.). São Paulo: Atlas.

De Brito, M. P. (2004). Managing reverse logistics or reversing logistics management? (Doctoral thesis). Erasmus University Rotterdam, Netherlands. Retrieved in 2016, April 3, from repub.eur.nl/pub/1132/EPS2004035LIS_9058920585_DEBRITO.pdf

Diehl, A., \& Tatim, D. (2004). Pesquisa em ciências sociais aplicadas: métodos e técnicas. São Paulo. Pearson Prentice Hall.

Freitas, H., \& Moscarola, J. (2002). Da observação à decisão: métodos de pesquisa e de análise quantitativa e qualitativa de dados. Revista de Administração de Empresas, 1(1), 130. http://dx.doi.org/10.1590/S1676-56482002000100006.

Gil, A. C. (1994). Métodos e técnicas de pesquisa social (4. ed.). São Paulo: Atlas.

Gonçalves, M. E., \& Marins, F. A. S. (2006). Logística reversa numa empresa de laminação de vidros: um estudo de caso. Gestão \& Produção, 13(3), 397-410.

http://dx.doi.org/10.1590/S0104-530X2006000300004. 
Guarnieri, P., Kovaleski, J. L., Stadler, C. C., \& Oliveira, I. V. (2005). A caracterização da logística reversa no ambiente empresarial em suas áreas de atuação: pós-venda e pósconsumo agregando valor econômico e legal. Tecnologia \& Humanismo, 19(1), 120-131. Retrieved in 2016, July 13, from http://www.resol.com.br/textos/e-book_2006_artigo_57.pdf

Hiratuka, C., Corazza, R. I., Rosandiski, E. N., Fracalanza, P. S., Luna, I., Oliveira, A. L. R., \& Vargas, M. (2013). Logística reversa para o setor de medicamentos. Brasília: Agência Brasileira de Desenvolvimento Industrial. Retrieved in 2015, August 12, from http://portal.anvisa.gov.br/wps/wcm/connect/6035fe804362f6fbaca0be0eb77d2a7a/Log\%C 3\%ADstica+Reversa+de+Medicamentos.pdf?MOD=AJPERES

Kabir, M. I. (2013). Reverse logistics in pharmaceutical industry. International Journal of Supply Chain Management, 2(1). Retrieved in 2018, September 28, from http://ojs.excelingtech.co.uk/index.php/IJSCM/article/view/691/396

Leite, P. R. (2000). Canais de distribuição reversos, $8^{a}$ parte. Revista Tecnologística, 6(61), 6067.

Leite, P. R. (2002). Logística reversa: nova área da logística empresarial. São Paulo: Publicare. Retrieved in 2016, July 11, from http://meusite.mackenzie.br/leitepr/LOG\%CDSTICA\%20REVERSA\%20\%20NOVA\%20\%C1REA\%20DA\%20LOG\%CDSTICA\%20EMPRESARIAL.pdf

Leite, P. R. (2009). Logística reversa: meio ambiente e competitividade (2. ed.). São Paulo: Pearson.

Lima, F. R., Jr., Osiro, L., \& Carpinetti, L. C. R. (2013a). Métodos de decisão multicritério para seleção de fornecedores: um panorama do estado da arte. Gestão \& Produção, 20(4), 781-801. http://dx.doi.org/10.1590/S0104-530X2013005000005.

Lima, P. F., Cavassini, A. C. M., Silva, F. A. T., Kron, M. R., Gonçalves, S. F., Spadotto, A., \& Lima, S. A. M. (2013b). Queixas técnicas e eventos adversos a medicamentos notificados em um hospital sentinela do interior de São Paulo, 2009-2010. Epidemiologia e Serviços de Saúde: Revista do Sistema Unico de Saúde do Brasil, 22(4), 679-686. http://dx.doi.org/10.5123/S1679-49742013000400014.

Machline, C., \& Amaral, J. B. C., Jr. (1998). Avanços logísticos no varejo nacional: o caso das redes de farmácias. Revista de Administração de Empresas, 38(4), 63-71. http://dx.doi.org/10.1590/S0034-75901998000400008.

Marin, N., Luiza, V. L., Osorio-de-Castro, C. G. S., \& Machado-dos-Santos, S. (2003). Assistência farmacêutica para gerentes municipais. Rio de Janeiro: Opas/OMS.

Mattar, F. N. (1996). Pesquisa de Marketing. São Paulo: Atlas.

Narayana, S. A., Elias, A. A., \& Pati, R. K. (2014). Reverse logistics in the pharmaceuticals industry: a systemic analysis. International Journal of Logistics Management, 25(2), 379398. http://dx.doi.org/10.1108/IJLM-08-2012-0073.

Organização Mundial da Saúde - OMS. Departamento de medicamentos essenciais e outros medicamentos. (2005). A importância da Farmacovigilância: monitorização da segurança dos medicamentos. Brasília: Organização Pan-Americana da Saúde. Retrieved in 2016, May 25, from http://bvsms.saude.gov.br/bvs/publicacoes/importancia.pdf

Rabelo, R. B. (2007). Vigilância pós-comercialização de produtos para a saúde: o desafio da rede sentinela (dissertação de mestrado). Fundação Oswaldo Cruz, Recife.

Reis, A. M. M., \& Perini, E. (2008). Desabastecimento de medicamentos: determinantes, consequências e gerenciamento. Ciência \& Saúde Coletiva, 13(Supl.), 603-610. http://dx.doi.org/10.1590/S1413-81232008000700009. PMid:21936164.

Rissi, N. M. N. (2011). Gestão de desvios técnicos no recebimento de medicamentos na Central de Abastecimento Farmacêutico.Faculdade de Medicina de Botucatu, Universidade Estadual Paulista, Botucatu. Retrieved in 2015, October 12, from http://hdl.handle.net/11449/88093 
Rocha, A. S., Teófilo, R. B., Sousa, P. C., \& Santos, L. (2008). Logística reversa como ferramenta de planejamento e controle das devoluções de mercadorias de uma empresa atacadista. In Anais do Simpósio de Excelência em Gestão e Tecnologia (SEGeT). Resende: AEDB.

Rogers, D. S., \& Tibben-Lembke, R. S. (1999). Going backwards: reverse logistics trends and practices. Reno: University of Nevada.

Rogers, D. S., Lambert, D. M., Croxton, K. L., \& García-Dastugue, S. J. (2002). The returns management process. International Journal of Logistics Management, 13(2), 1-18. http://dx.doi.org/10.1108/09574090210806397.

Sampaio, M., \& Csillag, J. M. (2010). Integração da cadeia de suprimentos da indústria farmacêutica. RAl: Revista de Administração e Inovação, 7(1), 109-130. Retrieved in 2016, May 1, from http://www.revistas.usp.br/rai/article/view/79161

Tobar, F., \& Yalour, M. R. (2001). Como fazer teses em saúde pública: conselhos e ideias para formular projetos e redigir teses e informes de pesquisa. Rio de Janeiro: Fiocruz.

Tuma, I. L., \& Carvalho, F. D., \& Marcos, J. F. (2009). Programação, aquisição e armazenamento de produtos para a saúde. In M. R. C. G. Novaes, N. N. R. Souza, E. D. R. Néri, F. D. Carvalho, H. M. O. M. Bernardino, \& J. F. Marcos (Eds.), Guia de boas práticas em farmácia hospitalar e serviços de Saúde - SBRAFH (Cap. 6.2, pp. 149-190). São Paulo: Ateliê Vide o Verso.

Viana, J. C., \& Alencar, L. H. (2012). Metodologias para seleção de fornecedores: uma revisão da literatura. Produção, 22(4), 625-636. http://dx.doi.org/10.1590/S010365132012005000067. 
Annex A. Checklist of medicines receipt.

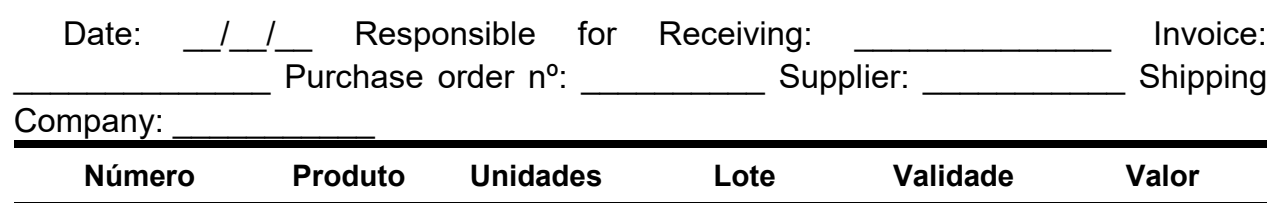

Quantity of volumes on Invoice: Was the delivery partial or total?

What is the amount of volumes delivered by the shipping company? STAGES

YES NO

Boarding boxes are not in perfect condition (wrinkled, torn, wet, dirty)

After opening those boxes not perfect, were some internal breakdown.

Any box is unsealed

The missing unit inside the boarding box

The primary packaging is missing in the secondary packaging.

The boarding box is missing.

The product delivered does not correspond to the invoice.

The product delivered does not correspond to the request.

The lot of the product does not correspond to the invoice.

The product shelf life is less than the acceptable.

There is a product that is not on the invoice.

The secondary packaging is missing information.

The secondary packaging contains errors or the absence of printing.

The security seal of secondary packaging is violated.

Post-marketing assessment

There was difficulty in communication with the supplier?

The supplier offered to resolve the occurrence?

What was the elapsed time for the resolution?

Comments: 